\title{
COVID-19: desperate times call for desperate measures
}

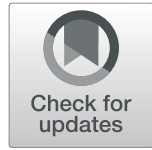

\author{
Stephan von Düring ${ }^{*}$ (D), Steve Primmaz and Karim Bendjelid
}

We read with interest the research letters published in Critical Care by Epstein et al. and Chase et al. who debate the utility of ventilator sharing in light of the COVID-19 pandemic $[1,2]$. The authors argue against the fact to ventilate two patients with a single ventilator.

Citing the joint statement from the AARC on multiple patients per ventilator, the authors recommend against ventilator sharing due to the lack of control of tidal volume $\left(V_{\mathrm{T}}\right)$, PEEP distribution, and pulmonary mechanic fluctuations. But are these valid arguments disqualifying concerns when demand for intubation and MV continues its upward trend? The COVID-19 pandemic has provoked a massive inflow of patients to ICUs, causing severe crisis due to the lack of equipment. As most ICU patients need intubation and MV [3], a major limitation is the lack of ventilators [4]. Some centers in Italy and the USA advocated a single ventilator for multiple patients.

The first days following intubation, patients with SARSCoV-2 pneumonia present high thoraco-pulmonary compliance and low pulmonary recruitability [5]. This implies that alveolar overdistension is rare and $V_{\mathrm{T}}$ can safely be higher than 4-6 ml/Kg/IBW.

The objective of ventilator sharing is to save a second life by buying time to find a second ventilator. It should ideally be reserved for two patients with the same gender and similar IBW and lung mechanics, who are sedated and paralyzed. A pressure-control setting is safest as $V_{\mathrm{T}}$ will be directly dependent on the respective lung compliances of both patients. Individual flow sensors can monitor $V_{\mathrm{T}}$. Since these lungs are poorly recruitable, high PEEP is not required and PEEP distribution will not play a major role. Minute ventilation can be estimated with individual $\mathrm{EtCO}_{2}$ readings or $\mathrm{PaCO}_{2}$ measurements.

\footnotetext{
* Correspondence: Stephan.vonDuring@hcuge.ch

Intensive Care Unit, Geneva University Hospitals, rue Gabrielle-Perret-Gentil 4, 1205 Geneva, Switzerland
}

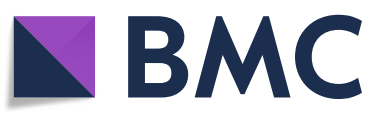

(c) The Author(s). 2020 Open Access This article is licensed under a Creative Commons Attribution 4.0 International License, which permits use, sharing, adaptation, distribution and reproduction in any medium or format, as long as you give appropriate credit to the original author(s) and the source, provide a link to the Creative Commons licence, and indicate if changes were made. The images or other third party material in this article are included in the article's Creative Commons licence, unless indicated otherwise in a credit line to the material. If material is not included in the article's Creative Commons licence and your intended use is not permitted by statutory regulation or exceeds the permitted use, you will need to obtain permission directly from the copyright holder. To view a copy of this licence, visit http://creativecommons.org/licenses/by/4.0/ The Creative Commons Public Domain Dedication waiver (http://creativecommons.org/publicdomain/zero/1.0/) applies to the data made available in this article, unless otherwise stated in a credit line to the data.
Dead space or changes in lung compliance of each patient will manifest themselves by an increase in $\mathrm{PaCO}_{2}$ $\mathrm{EtCO}_{2}$ gradient. Clamping of one of the endotracheal tubes (ET) during an inspiratory pause would allow one to measure actual plateau pressure and calculate lung compliance of the other patient. Risk of cross contamination is low with the placement of high-efficiency filters at the end of each ET.

Even if intensivists are trained to tailor treatment, nothing equips them to take the grueling and unethical live-or-die choice between patients due to resource scarcity. Ventilator sharing is a rescue therapy to be considered only in specific situations for a limited time. This extraordinary procedure could save lives. Desperate times call for desperate measures.

\section{Acknowledgements}

Not applicable.

\begin{abstract}
Authors' contributions K critically reviewed and revised the manuscript and approved the final manuscript as submitted. The authors read and approved the final
\end{abstract}

Funding

Availability of data and materials

Not applicable.

Ethics approval and consent to participate

Not applicable.

Consent for publication

Not applicable.

\section{Competing interests}

peting interests to declare. 
Received: 23 May 2020 Accepted: 2 June 2020

Published online: 09 June 2020

\section{References}

1. Epstein D, Hoffman Y, Dahoud G, Raz A, Miller A. Simultaneous ventilation of two simulated ARDS patients in COVID-19 pandemic. Crit Care. 2020; 24(1):214.

2. Chase JG, Chiew YS, Lambermont B, Morimont P, Shaw GM, Desaive T. Safe doubling of ventilator capacity: a last resort proposal for last resorts. Crit Care. 2020;24:222.

3. Mahase E. COVID-19: most patients require mechanical ventilation in first 24 hours of critical care. BMJ. 2020;368:m1201.

4. Truog RD, Mitchell C, Daley GQ. The Toughest Triage - Allocating Ventilators in a Pandemic. N Engl J Med 2020;382(21):1973-75.

5. Gattinoni L, Chiumello D, Rossi S. COVID-19 pneumonia: ARDS or not? Crit Care. 2020;24(1):154.

\section{Publisher's Note}

Springer Nature remains neutral with regard to jurisdictional claims in published maps and institutional affiliations. 